\title{
PENGARUH DISIPLIN KERJA, PENGAWASAN DAN MOTIVASI TERHADAP KINERJA KARYAWAN DI PT.MMW DI SIDOARJO
}

\author{
Ike Susanti \\ Universitas Islam Lamongan \\ ik33susanti@gmail.com
}

\begin{abstract}
ABSTRAK
Pengaruh Disiplin Kerja, Pengawasan dan Motivasi terhadap Kinerja karyawan PT Mitra Mutiara Woodtech di Sidoarjo. Dalam penelitian ini menggunakan metode baik secara kualitatif maupun secara kuantitatif dengan pengujian validitas dan reliabilitas, uji regresi berganda, uji koefisien korelasi, uji koefisien korelasi parsial, uji $t$ dan uji F. Adapun hasil dari penelitian ini adalah :Uji t (uji parsial) Variabel disiplin kerja (X1) Untuk variabel disiplin kerja / (X1), nilai t hitung yang diperoleh adalah sebesar 9,774 dan nilai signifikansinya adalah 0,000, nilai ini lebih kecil daripada $\alpha=$ 0,05,. Variabel pengawasan (X2) Untuk variabel pengawasan / (X2), nilai t hitung yang diperoleh adalah sebesar 8,657 dan nilai signifikansinya adalah 0,000, nilai ini lebih kecil daripada $\alpha=0,05$,. Variabel motivasi (X3) Untuk variabel motivasi / (X3), nilai t hitung yang diperoleh adalah sebesar 6,435 dan nilai signifikansinya adalah 0,000, nilai ini lebih kecil daripada $\alpha=0,05$,. Uji $F$ (bersama/simultan) Hasil perhitungan Uji $F$ yang dilakukan dengan bantuan program SPSS diperoleh nilai $F$ hitung sebesar 765,336. Nilai signifikansi yang diperoleh adalah sebesar 0,000, nilai signifikansi ini lebih kecil daripada nilai $\alpha$ yaitu 0,05. Dengan demikian berarti bahwa variabel bebas yang meliputi disiplin kerja (X1), pengawasan (X2) dan motivasi (X3) secara bersama / simultan berpengaruh terhadap kinerja (Y). Karena variabel X1 yaitu variabel disiplin kerja memiliki nilai korelasi parsial tertinggi yaitu sebesar 0,968 dibandingkan dengan variabel lainnya, maka variabel X1 yaitu disiplin kerja merupakan variabel bebas yang dominan mempengaruhi variabel terikat yaitu kinerja $(Y)$.
\end{abstract}

Kata Kunci : Disiplin kerja, Pengawasan, Motivasi dan Kinerja

\section{PENDAHULUAN}

Dalam rangka pembinaan aparatur pemerintah sebagai sumber daya manusia dalam organisasi pemerintah mempunyai andil yang cukup besar dalam menentukan keberhasilan pembangunan nasional, baik pembangunan fisik, maupun non fisik. Setiap organisasi apapun bentunya akan selalu berupaya semaksimal mungkin untuk mencapai tujuan organisasi yang bersangkutan dengan seefisien dan seefektif mungkin. Efisien dan efektif suatu organisasi sangat bergantung pada baik buruknya pengembangan anggota organisasi itu sendiri.

Disiplin kerja pada hakekatnya adalah untuk menumbuhkan kesadaran 
bagi para pekerja untuk melakukan tugas yang telah dibebankan, dimana pembentukannya tidak timbul dengan sendirinya, melainkan harus dibentuk melalui pendidikan formal maupun nonformal. Agar sumber daya manusia dapat berkualitas dan memiliki kinerja yang tinggi, maka perusahaan perlu memikirkan system agar bisa meningkatkan kinerja karyawan.

Motivasi merupakan salah satu usaha untuk meningkatkan kinerja pegawai. Motivasi dan kinerja adalah dua elemen yang konstruktif dan korelatif. Motivasi sebagai suatu kondisi dari dalam individu yang mendorong dan mengarahkan kegiatan individu tidak dapat diamati secara langsung. Dengan memahami peranan penting motivasi kerja pemimpin akan dapat mengembangkan prestasi kerja bawahanya, sehingga dapat meningkatkan kinerja pegawainya. Dari latar belakang masalah tersebut diatas, maka penulis untuk melakukan penelitian dengan judul : Pengaruh Disiplin kerja, Pengawasan dan Motivasi terhadap Kinerja karywan PT.Mitra Mutiara Woodtech di Sidoarjo.

\section{TINJAUAN PUSTAKA}

\subsection{Pengertian Disiplin}

Pada umumnya orang beranggapan bahwa seorang pegawai yang disiplin adalah bila mana seorang pegawai tersebut selalu datang secara tepat pada saat jam kerja. Menurut Nitisemito ( 1994:171) kedisiplinan diartikan sebagai : “ suatu sikap dan tingkah laku dan perbuatan yang sesuai dengan aturan dari organisasi baik yang tertulis maupun yang tidak tertulis." Kedisiplinan merupakan bentuk rasa tanggung jawab dan kewajiban bagi pegawai untuk menaati peraturan yang telah diteatapkan. Mengenai masalah disiplinan kerja, Putra (2001:25) mengatakan bahwa: " kedisiplinan harus ditanamkan sebagai rasa tanggung jawab dan sebagai kewajiban secara sadar, tanpa rasa takut terhadap sangsi, jika karyawan tersebut benar.

Untuk mengetahui dsiplin kerja pegawai dalam suatu instant dalam kondisi menurun, Nitisemito (1994:78) mengatakan bahwa tanda - tanda disiplin kerja menurun dapat dilihat dari :
a. Turunnya atau rendahnya produktivitas
b. Tingkat absensi yang naik/tinggi
c. Tingkat perpindahan karyawan yang tinggi


d. Kegelisahan dimana - mana

e. Tuntutan yang sering terjadi

Dalam hubungan dengan dasar dasar pendisiplinan tersebut maka Martoyo ( 1997:94) mengatakan : “ hal pertama yang lebih diperhatikan dalam proses pendisiplinan adalah pendisiplinan harus diletakkan pada pimpinan yang berwenang. Hal kedua yang perlu diperhatikan bahwa program pendisiplinan harus sesuai dengan keadaan yang bersifat logis. Hal yang ketiga adalah sifat pemimpin".

\subsection{Pengertian pengawasan}

Siagian (1986:88) mengahatakan bahwa :" Pengawasan adalah kegiatatan pemimpin atau manajer yang mengusahakan agar pekerjaan pekerjaan terlaksana sesuai dengan rencana yang telah ditetapkan dan hasil yang dikehendaki”. Berdasarkan pengertian tersebut bahwa untuk mengetahui pelaksanaan perencanaan yang telah ditetapkan ralisasinya diperlukan pengawasan yang tepat, karena melalui pengawasan diharapkan para karyawan dapat bekerja sesuai dengan ketentuan yang telah tertuang dalam perencanaan kerja sebelumnya. Agar supaya pengawasan dapat terealisir dengan baik tentunya harus didukung dengan usaha - usaha yang mantap. Adapun usaha - usaha dimaksud menurut Barthos (1995:145) adalah berikut :

1. Pengawasan preventif dilakukan dengan usaha - usaha sebagai berikut

a. Menentukan peraturan peraturan yang berhubungan dengan system, prosedur dan hubungan tata kerja.

b. Membuat pedoman atau manual sesuai dengan peraturan yang sesuai dengan peraturan yang telah ditetapkan.

c. Menentukan kedudukan, tugas, wewenang dan tanggung jawab

2. Pengawasan represif dilakukan dengan usaha sebagai berikut :

a. Dengan system komparatif yaitu mempelajari laporan kemajuan, membandingkan laporan laporan hasil laporan pekerjaan dengan rencana yang telah diputuskan sebelumnya, mengadakan analisa terhadap perbedaan - perbedaan tersebut termasuk faktor lingkungan yang dipengaruhinya.

b. Dengan system verifikatif yaitu : menentukan ketentuan yang berhubungan dengan prosedur 
pemeriksaan, mengadakan penilaian terhadap hasil pelaksanaan, pemeriksaan harus dilakukan secara periodic atau secara khusus.

c. Dengan system inspektif yaitu mengecek kebenaran dari suatu laporan yang dibuat oleh tgas pelaksanaannya.

d. Dengan system invertigatif yaitu menitik beratkan pada penyelidikan atau penelitian satu masalah yang bersifat negative.

\subsection{Pengertian Motivasi Kerja}

Pengertian motivasi menurut Sikula (1997:128), mengatakan bahwa : “ keseluruhan proses pemberian motif kepada para bawahannya sedemikian rupa sehinga mereka mau bekerja dengan ikhlas demi tercapainya tujuan. Menurut Ranupandojo dan Husnan ( 2005:197), menybutkan motivasi adalah merupakan suatu proses untuk mencoba mempengaruhi seseorang agar melakukan sesuatu yang kita inginkan.

\subsection{Pengertian Kepemimpinan}

Kepemimpinan / memimpin berbeda dengan pemimpin, untuk itu lebih jelas perbedaanya menurut
Handoko (2005:45) yaitu sebagai berikut :

1. Kepemimpinan /memimpin adalah proses mempengaruhi kegiatan kelompok yang terorganisasi dalam usaha menentukan tujuan dan pencapaiannya.

2. Pemimpin adalah orang yang mempunyai tugas untuk mengarahkan dan membimbing bawahan dan mampu memperoleh dukungan bawahan sehingga dapat mengerakkan mereka ( bawahn) kea rah pencapaian tujuan organisasi.

Tipe kepemimpinan menurut Tulus (1995:94) ada 5 typologi Kepemimpinan yaitu :

1. Otokrasi

2. Birokrat

3. Pelindung dan Penyelamat

4. Memajukan dan mengembangkan organisasi

5. Kompromi

\subsection{Pengertian Kinerja}

Kinerja merupakan tindakan tindakan atau pelaksannaan tugas yang telah diselesaikan oleh seseorang dalam kurun waktu tertentu dan dapat diukur Putra ( 2001:36-37). Hal ini dapat berkaitan dengan jumlah kualitas dan kuantitas pekerjaan yang dapat 
diselesaikan individu dalam kurun waktu tertentu. Ada beberapa cara untuk mengukur kinerja, yang secara umum antara lain : kuantitas kerja, kualitas kerja, pegetahuan tentang pekerjaan, pendapat atau pernyataan yang disampaikan, keputusan yang diambil, perencanaan kerja, dan daerah kerja.

Pengukuran Prestasi kerja : Harsono (2004:47) mengajukan enam criteria primer yang dapat digunakan untuk mengukur kinerja, yaitu :

1. Hasil pelaksanaan kegiatan mendekati kesempurnaan atau mendekati tujuan yang diharapkan

2. Jumlah yang dihasilkan

3. suatu kegiatan diselesaikan pada waktu yang dikehendaki dengan memperhatikan koordinasi output lainya serta waktu - waktu yang tersedia untuk kegiatan yang lain.

4. Tingkat sejauh mana penggunaan sumberdaya organisasi ( manusia, keuangan, tekhnologi, material ) dimaksimalkan untuk mencapai hasil tertinggi atau pengurangan kerugian dari setiap unit penggunaan sumberdaya.

5. Tingkat sejauh mana seseorang karyawan dapat melaksanakan suatu fungsi pekerjaan tanpa memerlukan pengawasan seorang supervisor untuk mencegah tindakan yang kurang diinginkan.

6. Tingkat sejauh mana karyawan memelihara harga diri, nama baik dan kerja sama diantara rekan kerja dan bawahan.

\section{METODOLOGI PENELITIAN}

Penelitian adalah suatu kegiatan yang dilakukan secara terencana dan sistematis untuk mendapatkan jawaban atau perencanaan masalah terhadap fenomena-fenomena tertentu. Dalam penelitian ini digunakan metode survey penjelasan yaitu survei yang menghubungkan variabel dan menguji variabel itu. Penelitian Survey ini menggunakan tipe penelitian penjelasan (explanatory reseach), yang memberikan penjelasan hubungan kausal antara variabel-variabel melalui pengujian hipotesis Dalam hal ini yang ingin dianalisis adalah pengaruh disiplin kerja, pengawasan dan motivasi terhadap Kinerja karyawan pada PT Mitra Mutiara Wootech di Sidoarjo. Pada penelitian ini mengambil sampel dari suatu populasi dan menggunakan kuesioner sebagai alat pengumpulan data pokok. Dalam penelitian memperoleh data melalui informasi primer tentang data yang berhubungan dengan variabel 
penelitian dikumpulkan dari responden dengan menggunakan kuisioner.

4. HASIL PENELITIAN DAN PEMBAHASAN

\subsection{Hasil Pengujian Validitas Data}

Untuk mengukur sah atau valid tidaknya suatu kuisioner dilakukan pengujian Validitas. Suatu butir pertanyan adalah valid jika terdapat korelasi yang signifikan yang ditunjukkan dengan nilai signifikansi yang kurang dari nilai $\alpha=0,05$. Hasil uji validitas disajikan pada tabel sebagai berikut :

Tabel 1. Hasil Uji Validitas

\begin{tabular}{|c|c|c|c|c|c|}
\hline No & Variabel & Item & $\begin{array}{l}\text { Koefisien } \\
\text { Validitas }\end{array}$ & Signifikan & Validitas \\
\hline \multirow[t]{4}{*}{1} & Disiplin & $\mathrm{X} 1-1$ & 0,872 & 0,000 & Valid \\
\hline & Kerja (X1) & $X 1-2$ & 0,879 & 0,000 & Valid \\
\hline & & $X 1-3$ & 0,942 & 0,000 & Valid \\
\hline & & $\mathrm{X} 1-4$ & 0,924 & 0,000 & Valid \\
\hline \multirow[t]{5}{*}{2} & Pengawasan & $\mathrm{X} 2-1$ & 0,861 & 0,000 & Valid \\
\hline & $(\mathrm{X} 2)$ & $\mathrm{X} 2-2$ & 0,896 & 0,000 & Valid \\
\hline & & $X 2-3$ & 0,925 & 0,000 & Valid \\
\hline & & $\mathrm{X} 2-4$ & 0,914 & 0,000 & Valid \\
\hline & & $X 2-5$ & 0,916 & 0,000 & Valid \\
\hline \multirow[t]{5}{*}{3} & Motivasi & X3-1 & 0,942 & 0,000 & Valid \\
\hline & Kerja (X3) & X3-2 & 0,924 & 0,000 & Valid \\
\hline & & X3-3 & 0,895 & 0,000 & Valid \\
\hline & & X3-4 & 0,870 & 0,000 & Valid \\
\hline & & X3-5 & 0,901 & 0,000 & Valid \\
\hline \multirow[t]{5}{*}{4.} & Kinerja (Y) & Y-1 & 0,902 & 0,000 & Valid \\
\hline & & Y-2 & 0,883 & 0,000 & Valid \\
\hline & & Y-3 & 0,876 & 0,000 & Valid \\
\hline & & Y-4 & 0,925 & 0,000 & Valid \\
\hline & & Y-5 & 0,914 & 0,000 & Valid \\
\hline
\end{tabular}

Sumber Data primer diolah 
Dari Tabel 1 diatas terlihat bahwa seluruh butir item pertanyaan memiliki nilai signifikansi kurang dari 0,05, dengan demikian dapat dikatakan bahwa seluruh butir pertanyaan adalah valid atau absah sehingga dapat dilakukan uji reliabilitas.

\subsection{Hasil pengujian reliabilitas}

Sedangkan Uji reliabilitas dapat dilihat dari uji statistik Cronbach Alpha, dimana bila nilai cronbach alpha $>0,6$ (Nunnally, 1969) dikatakan reliabel. Sedangkan hasil dari perhitungan reliabilitas diperoleh nilai alpha adalah sebagai berikut :

Tabel 2. Nilai Cronbach Alpha

\begin{tabular}{|c|r|}
\multicolumn{2}{|c|}{ Reliability Statistics } \\
\hline $\begin{array}{c}\text { Cronbach's } \\
\text { Alpha }\end{array}$ & N of Items \\
\hline .986 & 19 \\
\hline
\end{tabular}

Sumber : Lampiran SPSS

Dari uji reliabilitas diperoleh nilai cronbach alpha sebesar 0,986 nilai ini lebih besar dari 0,6. hal ini dapat dikatakan bahwa data penelitian tersebut reliabel / handal.

\subsection{Persamaan regresi linier berganda}

Pada pengujian ini dilakukan untuk mengetahui seberapa besar pengaruh dari masing-masing variabel bebas yang terdiri dari disiplin kerja (X1), pengawasan (X2) dan motivasi (X3) terhadap kinerja. Adapun hasil olah SPSS dapat dilihat pada tabel berikut :

Tabel 3. Nilai koefisien regresi

\begin{tabular}{|ll|r|r|r|c|}
\hline \multirow{2}{*}{ Model } & \multicolumn{2}{|c|}{$\begin{array}{c}\text { Unstandardized } \\
\text { Coefficients }\end{array}$} & $\begin{array}{c}\text { Standardized } \\
\text { Coefficients }\end{array}$ & \multirow{2}{*}{} \\
\cline { 2 - 5 } & \multicolumn{1}{|c|}{ B } & Std. Error & \multicolumn{1}{c|}{ Beta } & \multicolumn{1}{c|}{$\mathrm{t}$} \\
\hline 1 & (Constant) & .579 & .080 & & 6.387 \\
& X1 & .864 & .231 & .654 & 9.774 \\
& X2 & .658 & .219 & .576 & 8.657 \\
& X3 & .549 & .203 & .516 & 6.435 \\
\hline
\end{tabular}

a. Dependent Variable: $Y$

Sumber : Lampiran Hasil olahan SPSS.

Dari tabel diatas dibuat persamaan regresi sebagai berikut :

$\mathrm{Y}=0,579+0,864 \mathrm{X}_{1}+0,658 \mathrm{X}_{2}+$ $0,549 X_{3}$

Adapun penjelesan secara rinci dari persamaan regresi ini adalah:

a). Nilai konstanta sebesar 0,579, hal ini berari bahwa Nilai variabel prestasi kerja (Y) sebesar 0,579 tanpa dipengaruhi variabel bebas yaitu disiplin kerja (X1), pengawasan (X2) dan motivasi (X3) terhadap variabel terikat yaitu kinerja (Y).

b). Nilai koefisien regresi dari variabel disiplin kerja (X1) adalah 0,864, hal ini berarti bahwa jika nilai variabel disiplin kerja (X1) ditingkatkan sebesar satu satuan maka akan menyebabkan peningkatan nilai dari 
variabel kinerja (Y) sebesar 0,864 .

Dengan asumsi bahwa nilai dari variabel bebas lainnya adalah konstan atau nol.

c). Nilai koefisien regresi dari variabel pengawasan (X2) adalah 0,658 , hal ini berarti bahwa jika nilai variabel pengawasan (X2) ditingkatkan sebesar satu satuan maka akan menyebabkan peningkatan nilai dari variabel kinerja (Y) sebesar 0,658. Dengan asumsi bahwa nilai dari variabel bebas lainnya adalah konstan atau nol.

d). Nilai koefisien regresi dari variabel motivasi (X3) adalah 0,549, hal ini berarti bahwa jika nilai variabel motivasi (X3) ditingkatkan sebesar satu satuan maka akan menyebabkan peningkatan nilai dari variabel kinerja (Y) sebesar 0,549. Dengan asumsi bahwa nilai dari variabel bebas lainnya adalah konstan atau nol.

\subsection{Koefisien korelasi (R) dan determinasi simultan $\left(\mathbf{R}^{2}\right)$}

Koefisien korelasi (R) mengukur tingkat keeratan hubungan antara variabel bebas dan variabel terikat. Sedangkan Koefisien determinasi menunjukkan kontribusi variabel disiplin kerja (X1), pengawasan (X2) dan motivasi (X3) terhadap kinerja (Y). Sedangkan determinasi simultan $\left(\mathrm{R}^{2}\right)$ melihat kontribusi variabel disiplin kerja (X1), pengawasan (X2) dan motivasi (X3) terhadap kinerja (Y).

Hasil perhitungan SPSS mengenai koefisien korelasi dan koefisien determinasi ditunjukkan oleh tabel di bawah ini.

Tabel 4. Koefisien Korelasi dan

Determinasi

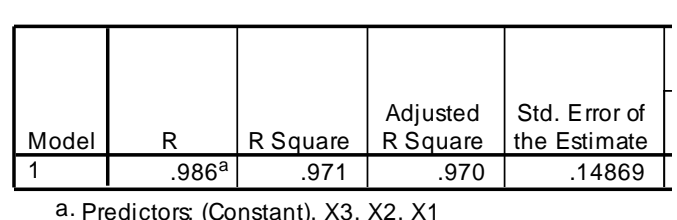

a. Predictors: (Constant), X3, X2, X1

Sumber : Lampiran Hasil olahan SPSS.

Dari tabel diatas dapat dikatakan bahwa nilai koefisien korelasi (R) adalah 0,986, hal ini dapat dikatakan bahwa terjadi hubungan yang kuat searah dari variabel independen yaitu disiplin kerja (X1), pengawasan (X2) dan motivasi (X3) dengan kinerja (Y). Artinya variabel independen yaitu disiplin kerja (X1), pengawasan (X2) dan motivasi (X3) ditingkatkan maka akan diikuti dengan peningkatan variabel kinerja (Y). Koefisien determinasi $\left(\mathrm{R}^{2}\right) \quad /\left(\mathrm{R}_{\text {squared }}\right)$ sebesar 0,971. Hal ini berarti naik turunnya variabel kinerja (Y) dipengaruhi variabel disiplin kerja (X1), pengawasan (X2) dan motivasi (X3) 
sebesar $97,1 \%$, dan sisanya sebesar $2,9 \%$ dipengaruhi oleh variabel lain yang tidak termasuk dalam model persamaan regresi dalam penelitian ini.

\subsection{Koefisien korelasi parsial}

Koefisien korelasi parsial menunjukkan pengaruh mana yang paling dominan dari variabel bebas meliputi disiplin kerja (X1), pengawasan (X2) dan motivasi (X3) terhadap variabel terikat yaitu kinerja (Y). Adapun hasil dari nilai koefisien korelasi parsial dapat ditunjukkan pada tabel 5 berikut ini.

Tabel 5. Koefisien Korelasi Parsial

Coefficients

\begin{tabular}{|c|c|c|c|c|c|c|c|c|c|}
\hline \multirow{2}{*}{\multicolumn{2}{|c|}{ Model }} & \multicolumn{2}{|c|}{$\begin{array}{c}\text { Unstandardized } \\
\text { Coefficients }\end{array}$} & \multirow{2}{*}{$\begin{array}{c}\begin{array}{c}\text { Standardized } \\
\text { Coefficients }\end{array} \\
\text { Beta }\end{array}$} & \multirow[b]{2}{*}{$t$} & \multirow[b]{2}{*}{ Sig. } & \multicolumn{3}{|c|}{ Correlations } \\
\hline & & B & Std. Error & & & & Zero-order & Partial & Part \\
\hline & (Constant) & .579 & .080 & & 6.387 & .000 & & & \\
\hline & $\mathrm{X} 1$ & .864 & .231 & .654 & 9.774 & .000 & .984 & .968 & .953 \\
\hline & $\mathrm{X} 2$ & .658 & .219 & .576 & 8.657 & .000 & .978 & .956 & .935 \\
\hline & X3 & .549 & .203 & .516 & 6.435 & .000 & .968 & .937 & .907 \\
\hline
\end{tabular}

a. Dependent Variable: $Y$

Sumber : Lampiran Hasil Olahan SPSS

Karena variabel X1 yaitu variabel Dalam pengujian secara parsial / disiplin kerja memiliki nilai korelasi parsial tertinggi yaitu sebesar 0,968 dibandingkan dengan variabel lainnya, maka variabel X1 yaitu disiplin kerja merupakan variabel bebas yang dominan mempengaruhi variabel terikat yaitu kinerja (Y). sendiri-sendiri ini menggunakan uji $\mathrm{t}$ pada $\alpha=0,05$ atau $p<0,05$ sebagai taraf signifikansi untuk melihat pengaruh dari variabel disiplin kerja (X1), pengawasan (X2) dan motivasi (X3) terhadap kinerja (Y).

Nilai t hitung yang diperoleh dari hasil pengolahan SPSS disajikan pada 4.6 Uji t (uji parsial) tabel 6 di bawah ini :

Tabel 6. Nilai $t_{\text {hitung }}$ dan Signifikansi

\begin{tabular}{|l|c|c|l|}
\hline \multicolumn{1}{|c|}{ Variabel } & $\mathbf{T}_{\text {hitung }}$ & signifikansi & \multicolumn{1}{|c|}{ Keterangan } \\
\hline Disiplin kerja (X1) & 9,774 & 0,000 & Berpengaruh \\
\hline Pengawasan (X2) & 8,657 & 0,000 & Berpengaruh \\
\hline Motivasi (X3) & 6,435 & 0,000 & Berpengaruh \\
\hline
\end{tabular}


Berdasarkan hasil pengolahan data menggunakan SPSS diperoleh t hitung yang disajikan pada tabel di atas, setelah itu dilakukan interpretasi hasil pengujian sebagai berikut :

1) Variabel disiplin kerja (X1)

Untuk variabel disiplin kerja / (X1), nilai t hitung yang diperoleh adalah sebesar $\quad 9,774$ dan nilai signifikansinya adalah 0,000 , nilai ini lebih kecil daripada $\alpha=0,05$, sehingga dapat dikatakan bahwa variabel disiplin kerja (X1) berpengaruh terhadap variabel terikat kinerja (Y)

2) Variabel pengawasan (X2)

Untuk variabelpengawasan / (X2), nilai t hitung yang diperoleh adalah sebesar 8,657 dan nilai signifikansinya adalah 0,000 , nilai ini lebih kecil daripada $\alpha=0,05$, sehingga dapat dikatakan bahwa variabel pengawasan $(\mathrm{X} 2)$ berpengaruh terhadap variabel terikat kinerja (Y).

3) Variabel motivasi (X3)

Untuk variabel motivasi / (X3), nilai t hitung yang diperoleh adalah sebesar 6,435 dan nilai signifikansinya adalah 0,000 , nilai ini lebih kecil daripada $\alpha$ $=0,05$, sehingga dapat dikatakan bahwa variabel motivasi (X3) berpengaruh terhadap variabel terikat kinerja (Y).

\subsection{Uji F bersama / simultan}

Dalam pengujian secara bersama / simultan ini menggunakan uji $\mathrm{F}$ pada $\alpha=0,05$ atau $p<0,05$ sebagai taraf signifikansi untuk melihat pengaruh secara bersama dari variabel disiplin kerja (X1), pengawasan (X2) dan motivasi (X3) terhadap kinerja (Y).

Nilai t hitung yang diperoleh dari hasil pengolahan SPSS disajikan pada tabel 7 di bawah ini :

Tabel 7. Nilai F hitung dan Signifikansi

ANOV A

\begin{tabular}{|c|c|c|c|c|c|c|}
\hline \multicolumn{2}{|c|}{ Model } & $\begin{array}{l}\text { Sum of } \\
\text { Squares }\end{array}$ & $d f$ & Mean Square & $\mathrm{F}$ & Sig. \\
\hline \multirow[t]{3}{*}{1} & Regression & 50.760 & 3 & 16.920 & 765.336 & $.000^{a}$ \\
\hline & Residual & 1.503 & 47 & .022 & & \\
\hline & Total & 52.263 & 50 & & & \\
\hline
\end{tabular}

a. Predictors: (Constant), X3, X2, X1

b. Dependent Variable: $Y$

Sumber : Lampiran SPSS 
Sesuai dengan hasil perhitungan Uji F yang dilakukan dengan bantuan program SPSS diperoleh nilai $\mathrm{F}$ hitung sebesar 765,336. Nilai signifikansi yang diperoleh adalah sebesar 0,000 , nilai signifikansi ini lebih kecil daripada nilai $\alpha$ yaitu 0,05 . Dengan demikian berarti bahwa variabel bebas yang meliputi disiplin kerja (X1), pengawasan (X2) dan motivasi (X3) secara bersama / simultan berpengaruh terhadap kinerja (Y).

\section{PENUTUP}

\subsection{Simpulan}

Dari hasil penelitian yang penulis lakukan, maka penulis mengambil kesimpulan sebagai berikut :

1. Uji t (uji parsial)

a. Variabel disiplin kerja (X1)

Untuk variabel disiplin kerja / (X1), nilai t hitung yang diperoleh adalah sebesar $\quad 9,774$ dan nilai signifikansinya adalah 0,000 , nilai ini lebih kecil daripada $\alpha=0,05$, sehingga dapat dikatakan bahwa variabel disiplin kerja (X1) berpengaruh terhadap variabel terikat kinerja (Y)

b. Variabel pengawasan (X2)

Untuk variabelpengawasan / (X2), nilai t hitung yang diperoleh adalah sebesar 8,657 dan nilai signifikansinya adalah 0,000 , nilai ini lebih kecil daripada $\alpha=0,05$, sehingga dapat dikatakan bahwa variabel pengawasan $(\mathrm{X} 2)$ berpengaruh terhadap variabel terikat kinerja (Y).

c. Variabel motivasi (X3)

Untuk variabel motivasi / (X3), nilai t hitung yang diperoleh adalah sebesar 6,435 dan nilai signifikansinya adalah 0,000 , nilai ini lebih kecil daripada $\alpha$ $=0,05$, sehingga dapat dikatakan bahwa variabel motivasi (X3) berpengaruh terhadap variabel terikat kinerja (Y).

2. Uji F (bersama/simultan)

Hasil perhitungan Uji $F$ yang dilakukan dengan bantuan program SPSS diperoleh nilai F hitung sebesar 765,336. Nilai signifikansi yang diperoleh adalah sebesar 0,000 , nilai signifikansi ini lebih kecil daripada nilai $\alpha$ yaitu 0,05 . Dengan demikian berarti bahwa variabel bebas yang meliputi disiplin kerja (X1), pengawasan (X2) dan motivasi (X3) secara bersama / simultan berpengaruh terhadap kinerja (Y).

3. Karena variabel X1 yaitu variabel disiplin kerja memiliki nilai korelasi parsial tertinggi yaitu sebesar 0,968 
dibandingkan dengan variabel lainnya, maka variabel X1 yaitu disiplin kerja merupakan variabel bebas yang dominan mempengaruhi variabel terikat yaitu kinerja (Y).

\subsection{Saran}

Adapun saran yang penulis rekomendasikan adalah :

1. Sebaiknya untuk menumbuhkan tingkat kesadaran bagi para pekerja untuk melakukan tugas yang telah dibebankan, maka sebaiknya diberikan motivasi agar setiap karyawan memiliki tingkat disiplin kerja yang tinggi. Selain itu untuk mengendalikan karyawan perlu juga diberikan sangsi-sangsi tegas bagi karyawa yang melanggar peraturan organisasi yang sudah ditetapkan.

2. Perlu adanya pengawasan yang baik, sebab dengan pengawasan yang preventif dan kontinyu, maka disiplin kerja karyawan dapat meningkat..

3. Peranan motivasi dalam meningkatkan kerja karyawan sangat penting, antara lain agar motivasi yang diberikan dalam bentuk bimbingan maupun pelatihan dapat menggerakkan setiap karyawan untuk bisa bekerja mencapai kinerja yang diharapkan.

\section{DAFTAR PUSTAKA}

Barthos, Basir 1995, Manajemen Sumber Daya Manusia, Cetakan ke tiga, Bumi Aksara, Jakarta

Handoko,T.Hani 2005. Manajemen Personalia dan Sumber Daya Manusia, Penerbit BPFE Yogyakarta.

Harsono, 2004, Manajemen Personalia dan Sumber Daya Manusia, Penerbit BPFE Yogyakarta.

Husnan, Suad. 2005, Manajemen Personalia, Penerbit BPFE Yogyakarta.

Martoyo, Susilo.1997. Manajemen Sumber Daya Manusia. Edisi ke Empat, PT Gramedia Pustaka Utama.

Nitisemito, Alex S. 1994, Management Personalia, Penerbit Ghalia Indonesia, Jakarta.

Putra, J Ravianto, 2001, Manajemen Personalia dan Sumber Daya Manusia, Penerbit BPFE Yogyakarta

Sikula F,Andrew.1997. Manajemen Sumber Daya Manusia, Penerbit BPFE

Yogyakarta 
Siagian, Sondang P. 1986, Filsafat

Administrasi, Penerbit Gunung Agung

Tulus, Moh Agus.1995, Manajemen Sumber Daya Manusia, Edisi ke Empat, PT Gramedia Pustaka Utama. 